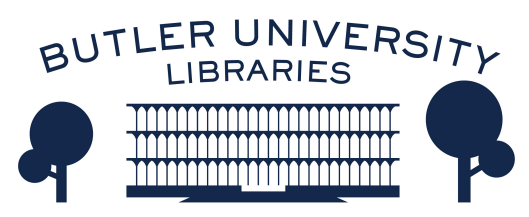

Journal of Hindu-Christian Studies

Volume 14

Article 7

January 2001

\title{
Heirarchies in the Nature of God? Questioning The "Saguna- Nirguna" Distinction in Advaita Vedanta
}

Anantanand Rambachan

Follow this and additional works at: https://digitalcommons.butler.edu/jhcs

Part of the Religion Commons

\section{Recommended Citation}

Rambachan, Anantanand (2001) "Heirarchies in the Nature of God? Questioning The "Saguna-Nirguna" Distinction in Advaita Vedanta," Journal of Hindu-Christian Studies: Vol. 14, Article 7.

Available at: https://doi.org/10.7825/2164-6279.1250

The Journal of Hindu-Christian Studies is a publication of the Society for Hindu-Christian Studies. The digital version is made available by Digital Commons @ Butler University. For questions about the Journal or the Society, please contact cbauman@butler.edu. For more information about Digital Commons @ Butler University, please contact digitalscholarship@butler.edu. 


\title{
Hierarchies in the Nature of God? Questioning The Saguna-Nirguna Distinction in Advaita Vedanta
}

\author{
Anantanand Rambachan \\ Saint Olaf College
}

THE Advaita tradition has not merely been the focus of my scholarly work; my personal world-view has been shaped by its insights and I continue to be deeply influenced by its understanding of human existence. One cannot, however, ignore the challenges of claims which are different from one's own and my encounter with other Hindu traditions and other religions has led to a reevaluation of many aspects of my Advaita heritage. I have chosen, in what follows, to reflect on how my original understanding is being transformed by encounters with other traditions by focusing on the Advaita representation of brahman as nirguna and saguna. A more detailed treatment, both of the problems of this doctrine and the implications, for Advaita, of an alternative expression of the nature of brahman, exceeds the limits of this study and is the focus of my current scholarly project. In this study I must be content with sharing some of the specific questions I have asked, selective elements of my critique, and the general direction of my re-assessment of the Advaita doctrine of God.

Contemporary commentators on the Advaita Vedanta tradition commonly distinguish between two orders or levels of the absolute (brahman) and propose a hierarchy between these. One is para or higher brahman and the other is apara or lower brahman." The higher brahman is referred to as nirguna brahman, the absolute non-dual brahmon, transcending time, space, causation and relations. It is beyond all action and change and free from any multiplicity. Nirguna brahman, so characterized, is not responsible for the world-creation, since it is presented as being beyond activity and causation.

On the one hand there is brahman which is One only, which is formless, attributeless and actionless. On the other, there is the world of perceivable objects, diverse in name and form. This is the phenomenal world, the world of the many. Brahman is one; the world is many, brahman is attributeless, nirguna; objects are qualified by attributes, they are saguna. Brahman has no name or form; objects have different forms and names. Brahman is inactive and permanent; the objects of the world are active and subject to change. What is the link between the two? What is the modus operandi of the transition of the One into the many? $?^{2}$

The modus operandi or connecting principles between nirguna brahman and the world, according to this viewpoint, is maya. Without maya, nirguna brahman cannot make the transition from impersonal consciousness to personal creator. ${ }^{3}$ It is brahman associated with maya which is the origin and source of the world and which is referred to as saguna brahman. Saguna brahman is also equated with isvara, the lord of the creation. ${ }^{4}$ Saguna brahman is regarded by Advaita interpreters as lower (apara) because, among things, it is conditioned and related to the world. "Saguna brahman is God as appearance and 
not as reality." Isvara is related to the world and defined through that relationship, whereas nirguna brahman is brahman-initself and beyond all definitions. It is higher (para) because it is neither cause nor effect.

\begin{abstract}
Brahman-in-itself is neither the cause nor the effect of anything. If it is the effect of something else, then it has a beginning, and whatever has a beginning must have an end. It means that it will cease to be eternal. If it is the cause of anything, then it becomes relational. In that case, it is not better than the things of the world which are relational. $^{6}$
\end{abstract}

The same writer adds that the association of brahman with maya represents a climb down in the status of brahman. Whereas there is no distinction between substance and attributes in nirguna brahman, saguna brahman possesses attributes (gunas) and this is another reason for characterizing saguna brahman as lower.?

The distinction between a higher and lower brahman is not just a mode of speaking about the absolute which is internal to the Advaita tradition. It is applied outside Advaita to evaluate the doctrine of God in other Hindu traditions as well as in other religions. It may not surprise one to note that the God of other Hindu traditions and other religions is generally equated with lower brahman. The language is often arrogant and supercilious.

It is Saguna-Brahman that men (sic) worship under different names and forms, such as Jaweh, Allah, Jesus, Rama Krishna, Siva and a myriad others. It is God as Saguna-Brahman that is endowed with such qualities as love, kindness, mercy, and justice. In brief, Saguna-Brahman is personal God. $^{8}$

This description of brahman as nirguna and saguna is not without problems and, in spite of its prevalence in Advaita rhetoric, deserves reconsideration. It suggests a bifurcation in the nature of brahman which is inconsistent with its non-dual nature. Such a distinction becomes particularly problematic when there is a hierarchical ordering and one is considered higher (para) and the other lower (apara). Surely, the nature of brahman does not admit of distinctions of any kind and the necessity and purpose of these must be queried and assessed. Is it, for example, a part of isvara's self-consciousness to regard brahman as having two levels of being, one higher and the other lower and to identify with the lower? The distinction also, as noted above, has implications for the Advaita understanding of and relationship with other traditions.

It seems to me that the main purpose of the Advaita interpreters, in proposing a higher and lower brahman, is to account for the origin of the universe in a sentient and intelligent cause, while, at the same time, "protecting" brahman from what the tradition sees to be the drawbacks and limitations of ascribing creatorship and a relationship with the world to brahman. Creatorship, and all that it implies in Advaita, is thus attributed to saguna brahman while nirguna brahman is seen as entirely free from all involvements in the world process except as the ground or substratum (adhisthana) of the creative process. Is the Advaita concern about the socalled defects and limitations of ascribing creatorship to brahman valid? Is it necessary to address this concern by proposing that brahmon possesses a two-fold nature, one higher and the other lower?

Let us begin by considering the issue of change and activity. Since the act of creation appears to imply change and activity and brahman, by definition, is free from all change and activity, brahman, it is so argued, cannot be directly involved in the world process. Such involvement is for the lower or saguna brahman. What is most interesting here is that the Advaita tradition which is particularly concerned, in the doctrine of nirguna brahman, with deconstructing anthropomorphic understandings of brahman raises a problem which is created by the anthropomorphic 
imagination. When the human being, limited by space and time engages in action, such action necessarily implies change. The same, however, ought not to be assumed for brahman who is the origin of space and time and who brings forth the world without any loss or change of self-nature (svarupa). It is not necessary, in other words, to suggest a hierarchical bifurcation in the nature of brahmon, in order to preserve brahman's nature, since the creative act does not alter or diminish this nature. Advaita interpreters are responding to a problem which, in fact, only arises from understanding the creative act of brahman on the analogy of finite human activity.

If we turn to the Upanisads, the primary authoritative sources of the Advaita tradition, we see that the many analogies used to discuss the relationship between brahman and the world, such as clay and clay-pots or gold and gold-ornaments, make a similar point. ${ }^{9}$ The world does not emerge from brahman in the same manner that gold ornaments are manufactured from gold. Gold, is after all, a finite object. The point of the analogy is that the fundamental nature of gold remains the same in spite of the production of multiple ornaments. Since gold is always gold, even with various ornaments, there is no need to propose a distinction in the nature of gold for the purpose of preserving its original nature. In a similar way, since the creation of the world, from brahman, does not deplete or alter its nature, an explanation which involves the suggestion of a dual nature is unnecessary.

There are several passages in the Upanisads suggesting that the activity of brahman is non-pareil. It is activity without change, as we normally construe it, or loss of nature. Isa Upanisad (4-5) describes the activity of brahman in a series of paradoxes.

(The spirit) is unmoving, one, swifter than the mind. The senses do not reach It as It is ever ahead of them. Though Itself standing still, It outstrips those who run. In It, the all intelligent air supports the activities of all beings.
It moves and it moves not; It is far and It is near; It is within all this and It is also outside all this. ${ }^{10}$

"Sitting," says the Katha Upanisad (I.2.21), "he moves far; lying he goes everywhere." In a well-known sequence of verses in the Bhagavadgita (13:15-17), Krsna enunciates the mystery of brahman as both immanent and transcendent, involved in the worldprocess and free from its finitude and limits.

Shining by the functions of the senses, yet freed from all the senses, unattached yet maintaining all, free from the qualities yet experiencing the qualities.

Outside and inside beings, those that are moving and not moving, because of its subtlety This is not comprehended. This is far away and also near.

Undivided yet remaining as if divided in all beings. This is to be known as the sustainer of beings, their devourer and creator. ${ }^{11}$

There is a very clear concern in the Upanisads to establish that brahman can be related to the world while at the same time not be limited by such relations. Katha Upanisad (II.2.11), for example, uses the analogy of the sun, which, though helping the eyes to see, is not tainted by the defects of the eye or of any other object. The text establishes brahman to be in all things and yet be free from the characteristics of the objects of the world. It is thus difficult to agree with the argument, cited above by the well-known Advaita commentator, $\mathrm{R}$. Balasubramanian, that if brahman is the cause of anything it becomes relational and, because of such relations, it is no better than things of the world. Brahman, as I am contending, can be both intelligent (nimitta) and material (upadana) cause of the world does not imply limits of the kind alluded to by Balasubramanian. Its relationship to the world, numerous Upanisadic texts emphasize, does not reduce it to a worldly object. Advaita commentators seem to assume, unnecessarily and unfortunately, that the fact of having a relationship with the 
world is problematic and find a need, therefore, to propose a lower brahman related to the world and a higher brahman unrelated to the world. The unique immanent-transcendent nature of the brahman-world relationship appears to have been overlooked.

Another reason commonly advanced for distinguishing between brahman as saguna and nirguna and for granting a lower status to saguna brahman is the argument that whereas there is no distinction between substance and attributes (gunas) in nirguna brahman, saguna brahman possesses attributes and there exists a distinction of substance and attributes. This contention also requires careful scrutiny since it further underlines the questionable dichotomy in the nature of brahman.

Brahman is consistently described in the Upanisads as one only and non-dual. ${ }^{12}$ This is interpreted in Advaita to mean that brahman is free from limitations and distinctions of all kinds. Since brahman is all-pervasive, it is free from spatial limitation (desa pariccheda) which characterizes created objects. As an entity which has existed and will exist without any loss of nature, brahman not subject to time limitation (kala pariccheda). Since it constitutes the essential nature of everything that exists, brahman is free from the limitation of being one object (vastu pariccheda) separate and distinguishable from every other object. It is infinite (ananta) in all senses of the term.

The non-dual nature of brahman is also understood to mean that brahman is free form distinctions (bheda) of all kinds. In Advaita, three such distinctions are particularly highlighted. First, there is the distinction obtaining among objects belonging to different species (vijatiya bheda) such as plants and animals. Brahman is free from distinctions of this kind since there is no object which enjoys a separate ontological nature and existence from brahman. In this sense, brahman constitutes the essential nature of all that exists. Second, there is the distinction existing among different objects belonging to the same species (svajätiya bheda). Brahman, however, is not the name of a species and there are no objects similar to but different from brahman. Distinctions of this kind therefore, do not apply. Third, there is the distinction obtaining within a single object comprised of different parts and possessing different characteristics. A cow, for example, has legs, a tail, ears and a head. It also has color, shape and size. It is, in other words, internally differentiated. Brahman, on the other hand, has no internal distinctions. It is not a compound of diverse parts and natures and transcends distinctions such as those obtaining between substance and attributes or whole and parts. Brahman is indivisible and partless and beyond all definitions which are based on distinctions.

It is in the context of denying differences and distinctions of the kinds described above that we ought to understand the use of the term nirguna (lit. without qualities). While this term emphasizes the uniqueness of brahman and reminds us that brahman cannot be thought of or defined in the manner of limited objects, it does not refute the possibility of the world originating from brahman. Nirguna particularly denies the distinction of substance and attribute in brahman. This does not mean that one should regard brahman as a substance with no attributes. It means that brahman transcends the categories of both substance and attribute as well as the conventional distinction obtaining between these. Nirguna affirms the uniqueness of brahman's nature, but does not speak of the possibility of brahman as world-creator. To argue, as some Advaita commentators have done, that nirguna brahman cannot be the author of creation is to misconstrue the significance of the term.

Nirguna is also a potent reminder about the limits of conventional language in describing brahman. Words, according to the Advaita commentator, Śankara, define objects in four ways. They do so through categories denoting genus, actions, quality and relation. Words such as cow and horse, refer to genus, cook and teacher suggest actions, red and blue indicate qualities, and 
householder and cattleowner point to a relation or possession. ${ }^{13}$ Brahman does not belong to a species, and, as already suggested, transcends the distinction of substance and attribute. While it is the source of the world, it does not undergo a change of nature or become related to the world in ways that are limiting or nontranscendent. Since activity and relation generally imply a change of nature, conventional words have to be used cautiously in speaking about brahman. The term nirguna ought not to be used to disconnect brahman from the world and to present it as a bland and static reality incapable, unless conjoined with maya, of bringing forth the creation. The essential point is that just as brahman can create from itself without suffering a loss of nature or being limited by the world, the creative act does not also affect the essential unity of brahman's being which remains free from distinctions of every kind. This is the truth which must be emphasized and which eliminates the need for any hierarchical distinctions in the nature of brahman.

The Upanisads clearly distinguish between the mental concepts and images which we have about brahman and the reality of brahman's nature. The Taittiriya Upanisad twice describes brahman as that from which all words, with the mind return, having failed to reach. ${ }^{14}$ The Vedas, in speaking about brahman, are constrained to use conventional language derived from everyday usage and, since these emerge from our experience of finitude, can never directly signify brahman. Words are mere pointers to that which is beyond the meaning of all words and definitions. The concern to differentiate between a lower and higher nature in brahman betrays this significant Upanisadic insight about the limits of language in relation to brahman.

Nirguna brahman, it is argued, transcends the distinction between substance and attribute and is higher, whereas saguna brahman possesses attributes and is lower. The point, however, is that if the unity of brahman's nature precludes distinctions of all kinds, including, as we have seen, the distinction of substance and quality, the act of creation does not introduce any distinctions in brahman. The nature of brahman is the same before and after creation. In relation to creation, we must rightly speak of brahman as creator, lord, support, and as omniscient and omnipotent. These are indeed relational definitions of brahman. Surely, they must not be construed as implying a transformation in the nature of brahman or a "climb down in the status of brahman." Creation does not introduce hitherto non-existent distinctions in the nature of brahman, including the distinction of reality and appearance.

The problem and limits of language, it must be remembered, are also valid with reference to brahman as creator and in relation to the world. Here also, we must be conscious of the difference between the nature of brahman and our human metaphorical ways of speaking about brahman. Human speech about brahman, even when such speech, because of the limits of language, appears to imply divisions in brahman's nature does not, in actuality, imply any divisions. To posit omnipotence as an attribute of brahman does not mean that brahman possesses the attribute of omnipotence in the same way that a lotus has the color blue as its attribute. The act of creation and being in relation to the creation does not alter the unity of brahman. The need to distinguish between a higher and lower brahman incorrectly underlines this fear.

If the nature of brahman is not dual and does not become dual as a result of the creation of the world, we must also question the distinction made between what is intrinsic or essential in the nature of brahman (svarupalaksana) and what is extrinsic or non-essential (tatasthalaksana). ${ }^{15}$ Essential or intrinsic is equated with nirguna and non-essential and extrinsic with saguna. Creatorship and being in relation to the world are regarded as constituting the non-essential nature of brahman. The terminology of essential and non-essential is as unfortunate and as unnecessary as higher and lower since it 
introduces another distinction in the nature of brahman. The need for it also arises from the concern, identified earlier, that creatorship is limiting and defective. How could brahman possess non-essential characteristics if the basic distinction between substance and quality does not obtain?

The most unfortunate consequence of the distinction between a higher and lower brahman is the reduction in the significance of the world and human existence within it. The value of the world is surely diminished if it is associated with brahman's lower nature and if any kind of involvement of brahman in the world process is understood as a "climb down" on the part of brahman. The same devaluation ensues when the world is regarded as the result of nonessential character of brahman. This is an issue which deserves further analysis. The many problems in the hierarchical and supersessionist use of nirguna and saguna may be avoided by emphasis on the absence of distinctions in brahman before and after creation. While we must speak in our limited language about brahman in relation to the world, neither our world nor our language compromises the unity and fullness of brahman. We may see nirguna and saguna as complementary and necessary rather than exclusive and hierarchical. These terms point to brahman as both immanent and transcendent, as involved in the worldprocess and unlimited by it. In this view, one does not have to deny creatorship to brahman or to bifurcate brahman in order to preserve brahman's non-duality and transcendence. Saguna and nirguna are necessary poles in the paradoxical language without which one cannot speak of brahman.

\section{Notes}

1. See, for example, R. Puligandla, Fundamentals of Indian Philosophy
(Nashville: Abingdon Press, 1975), pp. 225-226.

2. P. Sandaranarayanan, What is Advaita? (Bombay: Bharatiya Vidya Bhavan, 1988), p. 46.

3. The significance of maya and its relationship to brahman and creation in Advaita is a subject which requires critical consideration. Such a discussion, however, is beyond the scope of this study.

4. The word "God" is more appropriately used for saguna and not nirguna brahman.

5. R. Puligandla, Fundamentals of Indian Philosophy, op. cit., p. 225.

6. R. Balasubramanian, "The Absolute and God," in R. Balasubramanian ed., The Tradition of Advaita (Delhi: Munshiram Manoharlal Publishers, 1994), p. 36.

7. See swami Satprakashananda, The Universe, God and God-Realization (St. Louis: The Vedanta Society of St. Louis, 1977), p. 77.

8. R. Puligandla, Jnana-Yoga: The Way of Knowledge (Lanham: University Press of America, 1985), p. 91.

9. See Chandogya Upanisad, Chapter 6 in S. Radhakrishnan ed., and trans., The Principal Upanisads (London: Allen and Unwin, 1953).

10. Radhakrishnan's translation.

11. The Bhagavadgita, trans. Winthrop Sargeant (Albany: State University of New York Press, 1993).

12. See, for example, Aitareya Upanisad (I.1) and Chandogya Upanisad (VI.2.I).

13. See The Bhagavadgita with the commentary of Sankara, trans. A. M. Sastry (Madras: Samata Books, 1979), 13:12.

14. yato vaco nivartante aprapya manasa saha.

15. For a discussion of this distinction see Karl H. Potter, The Encyclopedia of Indian Philosophies: Advaita Vedanta up to Sankara and His Pupils (Delhi: Motilal Banarsidass, 1981), pp. 73-76. 